\title{
Preliminary Magnetostratigraphy for the Jurassic-Cretaceous Transition in Porto da Calada, Portugal
}

\author{
Johanna Salminen, Jorge Dinis and Octávio Mateus
}

\begin{abstract}
We present a stratigraphic log supporting a preliminary magnetostratigraphy of a Tithonian-Berriasian section in Porto da Calada (Portugal). Based on biostratigraphy and reversed and normal magnetostratigraphy, the location of the Tithonian-Berriasian boundary is tentatively located at ca. $52 \mathrm{~m}$, not in disagreement with former proposals. Due to the occurrence of later remagnetization (diagenesis), the magnetostratigraphic definition of the Tithonian-Berriasian section at the Cabo Espichel (Portugal) location was not able to be established.
\end{abstract}

Keywords Lithostratigraphy • Magnetostratigraphy • Tithonian-Berriasian • Lusitanian Basin • Portugal

J. Salminen $(\bowtie)$

Department of Geosciences and Geology, and Department of Physics,

University of Helsinki, Helsinki, Finland

e-mail: johanna.m.salminen@helsinki.fi

J. Dinis

Department of Earth Science, University of Coimbra, Largo Marquês de Pombal, 3000-272 Coimbra, Portugal

e-mail: jodinis@dct.uc.pt

J. Dinis

IMAR-CMA, Marine and Environmental Reseach Centre, 3004-517 Coimbra, Portugal

O. Mateus

CICEGe, Departamento de Ciências da Terra, Faculdade de Ciências e Tecnologia, Universidade Nova de Lisboa, 2829-516 Caparica, Portugal

e-mail: omateus@fct.unl.pt

O. Mateus

Museu da Lourinhã, 2530-157 Lourinhã, Portugal

R. Rocha et al. (eds.), STRATI 2013, Springer Geology, 


\section{Introduction}

The Jurassic-Cretaceous boundary is still poorly understood and is the last system boundary without a GSSP. Furthermore, biostratigraphic correlations among palaeobiogeographical provinces are hampered by barriers to faunal exchange (e.g., Ogg et al. 2012). Dating by magnetostratigraphy coupled with regional correlations and biostratigraphy has been successfully used to make large-scale correlations. Earlier studies have placed the Tithonian-Berriasian boundary in various different positions, but currently the base of Chron M18r is assigned and is even a candidate as a correlation event marking the boundary (Ogg et al. 2012).

The onshore uppermost Jurassic to lowermost Cretaceous of the Lusitanian Basin (Western Portugal) has been the subject of numerous studies (Ramalho 1971; Rey 1972, 1993; Mateus 2006; Dinis et al. 2008; Myers et al. 2012). It includes several good exposures of the Jurassic-Cretaceous (J-K) transitions, for example, Porto da Calada, the Sintra-Cascais region, and Praia dos LagosteirosCabo Espichel. Despite the favourable exposure, the exact position of the J-K boundary is poorly known, due to the lack of good biostratigraphic markers in a complex stratigraphy, which records important variations in a coastal landscape that was still under the influence of the late Oxfordian to early Kimmeridgian rifting.

\section{Sampling and Methods}

We collected 102 standard cores from the Porto da Calada section (lat $39.04^{\circ} \mathrm{N}$, long $9.41^{\circ} \mathrm{W}$ ), and 72 standard cores and four oriented block samples from the Cabo Espichel section (lat $38.42^{\circ} \mathrm{N}$, long $9.22^{\circ} \mathrm{W}$ ). A portable field drill was used and cores were oriented using both sun and magnetic compasses.

Palaeomagnetic measurements for magnetostratigraphy were conducted in the magnetically shielded room of the palaeomagnetic laboratory of the Department of Geology and Geophysics at Yale University, US. Samples were stepwise thermally demagnetized in a nitrogen atmosphere using an ASC Scientific model TD-48SC furnace. Remanent magnetization was measured using an automated samplechanging system attached to a $2 \mathrm{G}$ cryogenic magnetometer (Kirchvink et al. 2008). Sister specimens from the same cores were stepwise demagnetized using the alternating field (AF) method and a $2 \mathrm{G}$ cryogenic magnetometer in the Solid Earth Geophysics Laboratory at the University of Helsinki. Due to high-coercivity minerals in some of the samples, the thermal method was more effective. 


\section{Results of Magnetic Studies}

The natural remanent magnetization (NRM) intensity for Porto da Calada samples was generally in the order of $10^{-3} \mathrm{~A} / \mathrm{m}$ and magnetic susceptibility in the order of $10^{-4} \mathrm{SI}$, being typical for sedimentary rocks. NRM and susceptibility values depend on lithology, and limestone shows the lowest values (Fig. 1). The majority of the samples were totally cleaned during the thermal demagnetization and vectors decayed to origin, indicating that ChRM was successfully obtained and that no higher coercivity/unblocking temperature component was present. The colour of these fairly fine-grained samples was light or dark grey. Normal and reversed ChRM directions were obtained. Due to later diagenesis, a few samples of yellow and red colour did not reveal the original magnetization direction.

The Cabo Espichel samples had been totally remagnetized by post-formation processes and therefore did not reveal the original remanent magnetization direction.

\section{Stratigraphy}

At the Porto da Calada section, the Assenta member of the Lourinhã Formation is Tithonian in age. The Lourinhã Formation is Kimmeridgian-Tithonian in age, confidently biostratigraphically dated by numerous invertebrates and vertebrates (see Mateus 2006, and Ribeiro and Mateus 2012) and by strontium stable isotope curves (Schneider et al. 2009). The foraminifera, namely Anchispirocyclina lusitanica (Egger 1902), and ostracods of the 37-40 m limestone level (Fig. 1) (Rey 1972), are similar to the regional Tithonian assemblages (Ramalho 1971). Dinocysts of the 65-73 m interval are considered as representing the early to middle Berriasian boundary (Berthou and Leereveld 1990). The unconformity between the Porto da Calada and Vale de Lobos formations is dated by regional tectonostratigraphic correlation as late Berriasian (Dinis et al. 2008). In this section, two dinosaurs were identified: axial and postcranial parts of Ankylosauria below the J$\mathrm{K}$ boundary, and one tail spine of Stegosauridae above it, both chronologically consistent with the magnetostratigraphy.

Because the results from Cabo Espichel cannot be used for synsedimentary stratigraphic purposes, this outcrop is not discussed here.

\section{Discussion and Conclusions}

Based on the results for the Porto da Calada section, we correlate the reversed magnetozone at $33 \mathrm{~m}$ in the stratigraphic log with the M19r1 anomaly and the normal magnetozone between 35 and $51 \mathrm{~m}$ with M19n1 (Fig. 1). Following the 


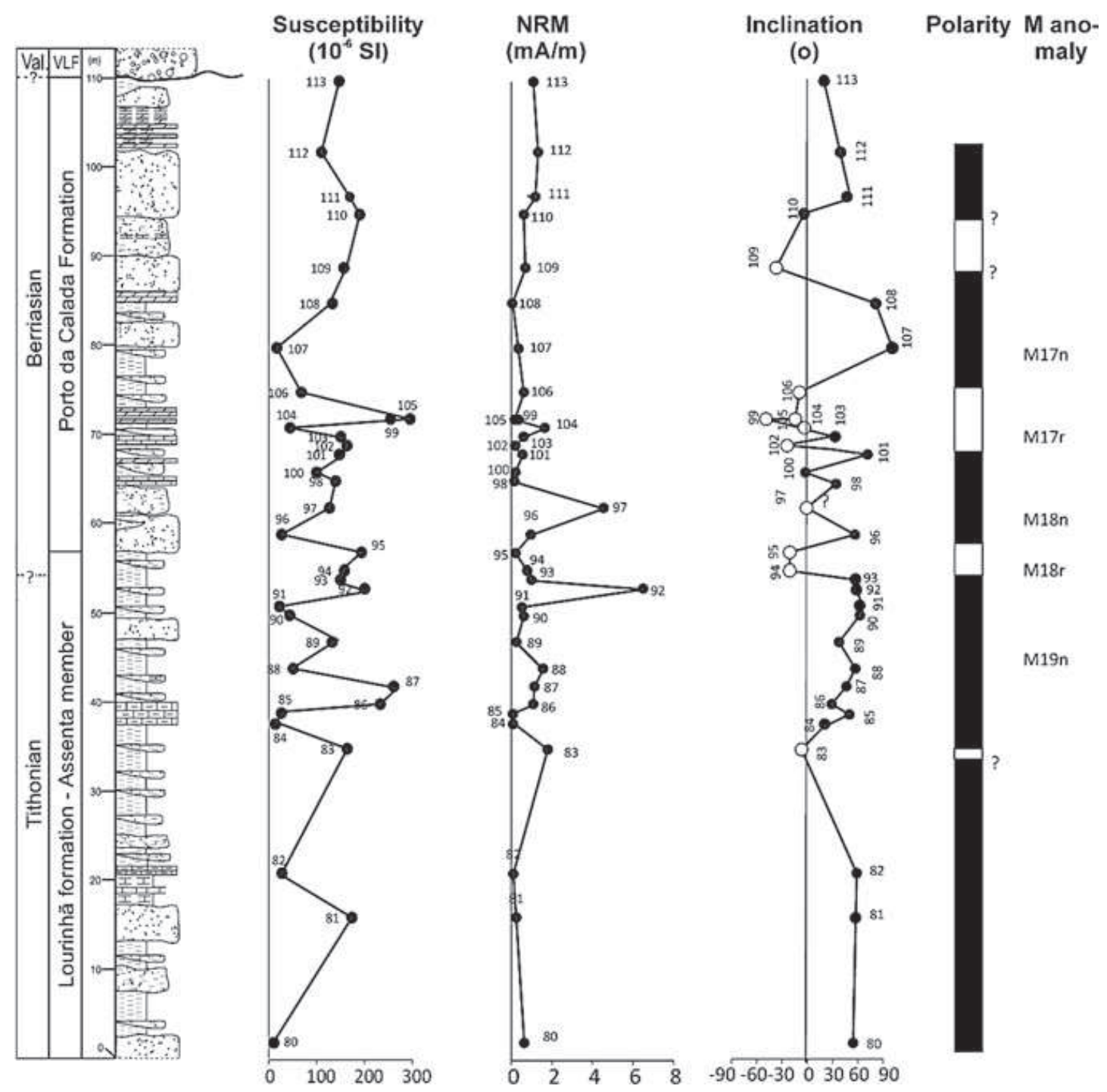

Fig. 1 Stratigraphy of the Porto da Calada section (Portugal): variation in magnetic susceptibility, intensity, inclination of ChRM, polarity column, and M-anomalies. Black (white) indicates normal (reversed) polarity

Ogg et al. (2012) scale, we place the J-K Tithonian-Berriasian boundary at the base of magnetozone M18r, at around $52 \mathrm{~m}$ of the $\log$. This position is an improvement over previous proposals for this outcrop, namely that of Rey (1993), which tentatively located the J-K boundary at the base of the Porto da Calada Formation (at our $60 \mathrm{~m}$ ) as a best fit between available biostratigraphy and regional correlations. However, it must be stressed that the proposed position of the $\mathrm{J}-\mathrm{K}$ boundary is tentative, due to the scarcity of fossils and the uncertainties in their age significance in the studied succession. 


\section{References}

Berthou, P.-Y., \& Leereveld, H. (1990). Stratigraphic implications of palynological studies on Berriasian to Albian deposits from western and southern Portugal. Review Palaeobotany and Palynology, 66, 313-344.

Dinis, J. L., Rey, J., Cunha, P. P., Callapez, P. M., \& Reis, R. P. (2008). Stratigraphy and allogenic controls on the western Portugal Cretaceous: An updated synthesis. Cretaceous Research, 29, 772-780.

Egger, J. (1902). Der Bau der Orbitolinen und verwandter Formen. Abhandlungen der mathematisch-physikalischen Classe der königlich Bayerischen Akademie der Wissenschaften, 21(3), 577-600.

Kirschvink, J. L., Kopp, R. E., Raub, T. D., Baumgartner, C. T., \& Holt, J. W. (2008). Rapid, precise, and high-sensitivity acquisition of paleomagnetic and rock-magnetic data: Development of a low-noise automatic sample changing system for superconducting rock magnetometers. Geochemistry Geophysics Geosystems, 9. Q05Y01. doi: 10.1029/2007GC001856.

Mateus, O. (2006). Late jurassic dinosaurs from the morrison formation (USA), the Lourinhã and Alcobaça formations (Portugal), and the Tendaguru beds (Tanzania): A comparison. New Mexico Museum of Natural History and Science Bulletin, 36, 223-231.

Myers, T. S., Tabor, N. J., Jacobs, L. L., \& Mateus, O. (2012). Palaeoclimate of the late jurassic of Portugal: Comparison with the western united states. Sedimentology, 59, 1695-1717. doi:10.1111/j.1365-3091.2012.01322.x.

Ogg, J. G., Hinnov, L. A., \& Huang, C. (2012). Cretaceous. In F. M. Gradstein, J. G. Ogg., M. D. Schmitz, \& G. M. Ogg (Eds.), The Geologic Time Scale 2012 (2, pp.793-853). Elsevier : Oxford.

Ramalho, M. M. (1971). Contribution à l'étude micropaléontologique et stratigraphique du Jurassique Superieur et Crétacé Inferieur des environs de Lisbonne (Portugal). Memórias dos Serviços Geológicos de Portugal, 19(N.S.), p. 212.

Rey, J. (1972). Recherches géologiques sur le Crétacé inférieur de l'Estremadura (Portugal). Memórias dos Serviços Geológicos de Portugal, 21(N.S.), pp. 477.

Rey, J. (1993). Les unités lithostratigraphiques du Grupe de Torres Vedras (Estremadura, Portugal). Comunicações do Instituto Geológico e Mineiro, 79, 75-85.

Ribeiro, V., \& Mateus, O. (2012). Chronology of the late jurassic dinosaur faunas, and other reptilian faunas, from Portugal. Journal of Vertebrate Paleontology, Program and Abstracts, 27, p. 161 ISSN 1937-2809.

Schneider, S., Fürsich, F. T., \& Werner, W. (2009). Sr-isotope stratigraphy of the upper jurassic of central Portugal (Lusitanian basin) based on oyster shells. International Journal of Earth Sciences, 98(8), 1949-1970. 
Rogério Rocha · João Pais

José Carlos Kullberg · Stanley Finney

Editors

\section{STRATI 2013}

First International Congress on Stratigraphy

At the Cutting Edge of Stratigraphy
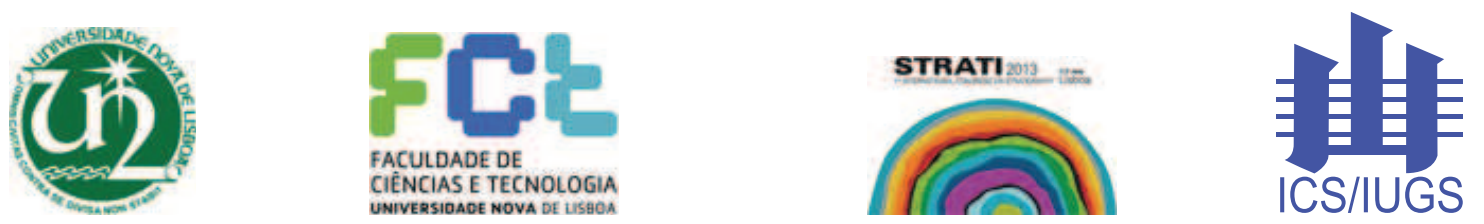

Earth Sciences Department

Centre in Geological Science and Engineering International Commission on Stratigraphy (IUGS) 
Editors

Rogério Rocha

João Pais

José Carlos Kullberg

CICEGe, Departamento de Ciências da Terra

Faculdade de Ciências e Tecnologia

Universidade Nova de Lisboa

Caparica

Portugal
Stanley Finney

Geological Sciences

California State University, Long Beach

Long Beach, CA

USA

ISBN 978-3-319-04363-0

ISBN 978-3-319-04364-7 (eBook)

DOI 10.1007/978-3-319-04364-7

Springer Cham Heidelberg New York Dordrecht London

Library of Congress Control Number: 2014931766

(C) Springer International Publishing Switzerland 2014

This work is subject to copyright. All rights are reserved by the Publisher, whether the whole or part of the material is concerned, specifically the rights of translation, reprinting, reuse of illustrations, recitation, broadcasting, reproduction on microfilms or in any other physical way, and transmission or information storage and retrieval, electronic adaptation, computer software, or by similar or dissimilar methodology now known or hereafter developed. Exempted from this legal reservation are brief excerpts in connection with reviews or scholarly analysis or material supplied specifically for the purpose of being entered and executed on a computer system, for exclusive use by the purchaser of the work. Duplication of this publication or parts thereof is permitted only under the provisions of the Copyright Law of the Publisher's location, in its current version, and permission for use must always be obtained from Springer. Permissions for use may be obtained through RightsLink at the Copyright Clearance Center. Violations are liable to prosecution under the respective Copyright Law. The use of general descriptive names, registered names, trademarks, service marks, etc. in this publication does not imply, even in the absence of a specific statement, that such names are exempt from the relevant protective laws and regulations and therefore free for general use.

While the advice and information in this book are believed to be true and accurate at the date of publication, neither the authors nor the editors nor the publisher can accept any legal responsibility for any errors or omissions that may be made. The publisher makes no warranty, express or implied, with respect to the material contained herein.

Printed on acid-free paper

Springer is part of Springer Science+Business Media (www.springer.com) 